\title{
HAKIKAT ILMU \\ DALAM PEMIKIRAN ISLAM
}

\section{Arqom Kuswanjono}

Fakultas Filsafat Universitas Gadjah Mada

Email: arqomk@yahoo.com

\begin{abstract}
Abstrak
Banyak orang sering mengonotasikan ilmu pengetahuan dengan Barat. Namun, jika dilacak secara historis, Islam memiliki kontribusi yang sangat besar dalam mengembangkan ilmu pengetahuan. Oleh karena itu, penelitian ini bertujuan untuk membandingkan karakter ilmiah dari Barat dan Islam, menganalisis perkembangan ilmu pengetahuan di Islam dan menemukan sifat ilmu dalam Islam. Ini adalah penelitian kepustakaan dengan menggunakan metode hermeneutik dengan unsur-unsur metode berupa deskripsi, verstehen dan interpretasi. Objek material adalah pemikiran Islam sedangkan objek formal adalah filsafat ilmu. Hasil penelitian ini menunjukkan bahwa ada karakteristik yang khas antara sains Barat dan Islam baik dari aspek ontologi, epistemologi dan aksiologi. Perbedaan yang paling mencolok adalah pada ada dan tidaknya pengakuan keberadaan Allah. Keilmuan Islam berasal dari Nabi Muhammad yang kemudian diteruskan para sahabat dan pemikir Islam berikutnya. Adapun sifat ilmu dalam Islam mencakup fasilitas, proses dan tujuan. Secara epistemologis hal ini bermakna bahwa Islam menerima rasio dan rasa, serta wahyu dan intuisi, sedangkan tujuan dari ilmu adalah untuk mengungkapkan kebenaran dalam mengejar Kebenaran Tertinggi.
\end{abstract}

Kata-kata kunci: filsafat, ilmu, Islam

\section{Abstract}

This research, entitled Essence of Religion in Islam. Many people often connote science with Western. However, if tracked historically, Islam have enormous contribution in developing of science. Therefore, this study aimed to compare the scientific character of the West and Islam, analyzing the development of science in Islamic and discover the nature of science in Islam. This is a library research using hermeneutic method with method elements are description, verstehen and interpretation. The material object is Islamic thought while the formal object is the philosophy of science. The results of this research indicate that there is a distinctive characteristic between Western science and Islam from the aspect of ontology, epistemology, and axiology. The most striking 
difference is the recognition of the existence of God. In its development, Islamic science actually stems from the Prophet Muhammad's own then forwarded the new companions subsequent Islamic thinkers. The nature of science in Islam includes facility, processes and objectives. Epistemologically, it means that Islam accepts ratio and sense as well as revelation and intuition, while the purpose of science is to reveal the truth in pursuit of Ultimate Truth.

Key words: philosophy, science, Islam

\section{PENDAHULUAN}

Ilmu dan manusia adalah dua realitas yang tidak dapat dipisahkan. Ilmu merupakan komponen penting dalam mendukung eksistensi manusia karena secara kodrati manusia adalah hewan yang berpikir (khayawan an-natiq). Ilmu, sebagai suatu realitas, namun sebaliknya juga dipengaruhi oleh cara pandang orang atas ilmu itu sendiri, yang kemudian dikenal sebagai paradigma. Ada beragam cara pandang atas ilmu meskipun di dalam dirinya ilmu itu sebenarnya bersifat objektif. Paradigma itulah yang akan mengarahkan ilmu tersebut dikembangkan. Ilmu, dengan kata lain ada secara as such (objektif) di satu sisi dan pandangan orang atas ilmu yang bersifat subjektif, di sisi lain.

Keberadaan ilmuwan, dalam perkembangan keilmuan Islam, sangat mendapat dukungan dari negara, bahkan negara menjadi salah satu inspirator munculnya sikap-sikap ilmiah dalam mengembangkan ilmu. Sebagai contoh, pada pemerintahan Muawiyah yang mempunyai keingintahuan yang tinggi tentang galaksi, pelangi, dan tempat terbitnya matahari, menstimulasi para ilmuwan seperti Ibnu Abbas untuk menjawab pertanyaan-pertanyaan itu sehingga lahirlah ilmu astronomi dan kosmologi.

Perkembangan keilmuan Islam juga distimulasi oleh pernyataanpernyataan dalam Al Quran untuk berpikir tentang alam semesta, misalnya terkait dengan penciptaan alam semesta, fenomena turunnya hujan, penciptaan manusia, dan lain-lain. Berdasarkan penjelasan tersebut tampak jelas cara Islam menempatkan wahyu sebagai sumber, sekaligus sarana yang sangat penting dalam ilmu pengetahuan. 
Karakter keilmuan dalam Islam memang khas, berbeda dengan karakter keilmuan Barat yang hanya mendasarkan pada rasio dan empiri. Intuisi dan wahyu, dalam Islam, menjadi bagian yang tidak terpisahkan dalam ilmu. Karakter keilmuan ini memberikan warna bagi perkembangan keilmuan yang ada. Keilmuan Barat bersifat pragmatis materialistis kering dari refleksi atas nilai yang bersifat spiritual, sedangkan keilmuan Islam sangat sarat dengan spiritualitas, bahkan ilmu dijadikan jalan untuk memahami dan mendekat kepada Tuhan.

Persoalan epistemologis keilmuan Barat yang hanya bersifat pragmatis materialistik tentu tidak lepas dari pandangan ontologis atas ilmu yang tidak mengakui adanya realitas yang metafisik, sebagaimana dipahami oleh August Comte bahwa saat ini eranya sudah positivistik. Ilmu sudah meninggalkan era yang teologis maupun metafisis. Hanya kebenaran rasional-empirik (ciri posistivisme) yang dapat dipercaya. Konsekuensi pandangan ini tentu nilai-nilai moralitas yang tidak dengan mudah dapat dipahami secara positivistik ditinggalkan, padahal sebenarnya nilai-nilai itu dapat menjadi pertimbangan dalam menentukan arah perkembangan ilmu dan bahkan mendasarinya.

Perkembangan keilmuan dalam Islam memiliki karakter yang berbeda. Kalau di Barat perkembangan ilmu diawali dengan situasi zaman yang tidak memungkinkan ilmu berkembang leluasa yaitu pada zaman Abad Pertengahan (atau dikenal sebagai zaman kegelapan il$\mathrm{mu}$ ), perkembangan keilmuan Islam tidak mengalami situasi itu. Sejak awal Islam mentabukan umatnya untuk berpikir yang bertentangan dengan agama. Berdasarkan ulasan latar belakang di atas, dapat ditarik kesimpulan bahwa penelitian ini menunjukkan relevansinya untuk dilakukan.

\section{KARAKTERISTIK FILSAFAT BARAT DAN ISLAM}

Filsafat dikenal sebagai mater scientiarium, yaitu induk dari segala ilmu. Filsafat selain keberadaannya mendahului ilmu, sekaligus meletakkan dasar-dasar yang kuat bagi perkembangan ilmu pengetahuan. Filsafat dikatakan sebagai induk dari segala ilmu, selain atas dasar 
alasan historis, juga dikarenakan kajian filsafat memiliki sifat begitu mendasar atau mengakar yang tidak lain merupakan suatu pencarian abadi terhadap kebenaran yang paling hakiki. Atas peran dari kajian filsafat itulah ilmu pengetahuan memiliki nafasnya untuk terus mengalami perkembangan. Memahami filsafat, akan sangat luas, dengan hamparan aliran pemikiran yang induknya berasal dari zaman Yunani Kuno, dengan jiwa bangsa Yunani yang tak pernah dibatasi oleh kekuasaan absolut raja atau kekuasaan pendeta yang mengendalikan agama, negara, dan segala paparan kehidupan (Kartodirdjo, 1990: 13). Dari hal tersebut dapat dipahami bahwa pemikiran filsafat memiliki hubungan erat dengan aspek lainnya, yang menjelaskan kondisi kultural yang menjadi akar tumbuhnya tiap aliran pemikiran. Pangkal dari kondisi ini adalah budaya Yunani Kuno yang memunculkan tradisi berpikir bebas yang terlepas dari belenggu dominasi otoritas eksternal.

Tradisi filsafat Barat diawali dengan perdebatan metafisis dalam pencarian terhadap kenyataan yang mengatasi dunia yang sekedar fisik yang tidak lain muncul dalam perdebatan idealisme Plato dan realisme Aristoteles. Plato menganggap bahwa seseorang tidak dapat mengatakan apakah suatu pernyataan itu benar kecuali kalau dia sebelumnya sudah tahu bahwa itu benar (Hunt, 2003: 99). Idea dalam hal ini dianggap sebagai prinsip yang apriori dan mampu mengatasi realitas dunia fisik. Aristoteles, di sisi yang lain, cenderung mencari landasan pengada yang benar-benar mampu bersifat menyeluruh, baik ta hyperphisika (mengatasi dunia fisik), maupun ta physika (dunia fisik) itu sendiri (Bakker, 1992: 14). Kedua pemikiran tersebut memberikan pijakan awal dalam perdebatan pemikiran filsafat yang kemudian akan memunculkan berbagai aliran pemikiran, karena tidak dapat dipungkiri, budaya pemikiran Barat tidak dapat terlepas dari Platonisme dan Aristotelisme yang sangat bernafaskan jiwa kebebasan Yunani, dan telah berpengaruh tidak hanya dalam perkembangan filsafat, tetapi juga di bidang ketatanegaraan, etika, dan pendidikan (Kartodirdjo, 1990: 14). Tradisi berpikir bebas (free thinking) dari bangsa Yunani inilah yang kemudian menjadi jiwa dari perkembangan pemikiran Barat, yang juga menjadi nafas dari perkembangan ilmu pengetahuan. 
Ilmu dalam sejarah perkembangannya tidak dapat dikatakan terlepas dari peranan filsafat karena pada dasarnya setiap praktik keilmuan akan selalu membutuhkan suatu landasan filosofis, khususnya dalam hal ini adalah keberadaan filsafat ilmu. Proses maupun hasil dari kegiatan keilmuan apapun sangat ditentukan oleh landasan filosofis yang mendasarinya, yang menjadi kerangka, memberi arah, dan corak dari keilmuan yang dihasilkan (Zubaidi, 2013: 7). Dapat dikatakan bahwa landasan filsosofis dalam praktik keilmuan yang memuat asumsi dasar dan paradigma keilmuan atau cara pandang terhadap ilmu tersebut, menjadi suatu landasan dalam melakukan pertimbangan-pertimbangan untuk menjalani setiap langkah keilmuan. Dapat dikatakan dengan kalimat yang lain, yaitu bahwa pada dasarnya suatu corak pemikiran filosofis terhadap ilmu tidaklah dapat terbatasi hanya pada lingkungan pemikiran di dunia Barat saja, hal ini dikuatkan oleh pandangan Peursen (1979: 2, 3) bahwa berfilsafat merupakan salah satu kemungkinan yang terbuka bagi setiap orang, yang tentu saja hal tersebut dikarenakan setiap manusia dengan kemampuan rasionalnya mampu berpikir dengan menerobos pengalaman sehari-hari dan mengambil jarak dari hal-hal ihwal. Filsafat tidak terbatasi oleh suatu lokalitas tertentu, tetapi bersifat terbuka dengan berpijak pada kondisi sosio-kultural tempat tumbuhnya dan dengan berlandaskan sikap kritis dalam pencarian esensi yang paling mutlak, yaitu kebenaran itu sendiri. Filsafat dalam fungsinya sebagai landasan filsosofis mempengaruhi perkembangan dari tegaknya suatu ilmu dalam setiap kondisi sosio-kultural.

Filsafat Barat yang sering kali dianggap sebagai pangkal dari kajian filsafat, sering diidentikkan dengan suatu penyajian sejarah perkembangan pemikiran yang berawal dari masa klasik sampai dengan post-modern. Di bawah besarnya pengaruh pemikiran Barat tersebut, namun demikian terdapat tradisi pemikiran lain yang berasal dari belahan bumi lainnya, seperti filsafat India, filsafat Cina, dan filsafat Islam yang memiliki kekhasan masing-masing. Apabila filsafat Barat cenderung menempatkan akal manusia sebagai sumber dari penelaahan dengan cara semakin hari semakin melepaskan diri dari objek, hal 
tersebut berbeda dengan filsafat Timur termasuk dalam hal ini filsafat Cina, India, dan juga Islam. Filsafat Cina dan India cenderung menempatkan penghayatan spiritual dalam suatu arah penyatuan sebagai sumbernya dalam mencapai pemahaman. Hal tersebut memperlihatkan bahwa kenampaan sosio-kultural dari tempat tumbuhnya pemikiran filosofis tersebut memiliki pengaruh yang cukup besar. Begitu pula dengan pemikiran filsafat Islam yang pernah menjadi penabur utama dari kesuburan ilmu pengetahuan ke seluruh penjuru dunia pada abad $8 \mathrm{M}$ sampai abad $12 \mathrm{M}$. Islam sendiri sebagai kekuatan politik internasional memiliki cakupan yang sangat luas sampai dengan ke luar Semenanjung Arabia, sehingga mencakup Suria, Palestina, Mesir, Afrika Timur, Spanyol, dan pulau-pulau Laut Tengah, seperti Sisilia, di Barat dan Mesopotamia (Irak), Persia, Asia Tengah, dan India di Timur (Nasution, 1982: 52). Hal tersebut memperlihatkan bahwa membahas tentang perkembangan filsafat Islam tidak dapat dibatasi begitu saja dengan batasan geografis tertentu seperti dengan filsafat Cina dan India. Membahas mengenai filsafat Islam, namun demikian akan mengarahkan pada kekhasannya yaitu keberadaan tokoh-tokoh pemikirnya yang berasal dari suatu umat yaitu umat Muslim dan sumber utama pengetahuannya adalah wahyu, yang dikodifikasi dalam AlQur'an. Dapat dikatakan bahwa perkembangan filsafat Islam ini berasal dari satu titik yang tidak dapat digoyahkan yaitu wahyu dalam Islam, yaitu Al-Qur'an.

Kekhasan dari filsafat Islam itulah yang kemudian mempengaruhi karakter dalam dunia keilmuannya. Islam sebagai latar teologis tentu saja tidak dapat terlepas dari keberadaan dogma-dogma yang dianggap fundamental. Al-Qur'an yang notabene adalah wahyu, dalam filsafat Islam berusaha dirasionalisasikan agar membumi dan mampu dikomunikasikan terhadap manusia, dan itulah fungsi dari akal manusia (al-'aql), yang dalam Islam sangat berimpitan dengan keberadaan al-qalb dalam proses memperoleh pengetahuan dan pemahaman terhadap dalil-dalil agama. Perubahan pemahaman terhadap al-'aql tersebut terutama setelah masuknya pengaruh filsafat Yunani, yang memahami al-'aql dengan arti yang sama sebagai nous (Naution, 1982: 8), Dari al- 
qalb yang mengarahkan pada suatu penghayatan bergeser pada nous yang dipahami sebagai daya berpikir yang terkonsentrasikan pada fungsi rasio manusia. Hal tersebut yang kemudian menyebabkan ilmu pengetahuan mampu berkembang dengan pesat dalam tradisi Islam tanpa menegasikan Islam sebagai agama.

Perkembangan pesat ilmu pengetahuan dalam Islam ini berada pada saat filsafat Barat berada di titik nadir, yaitu pada masa otoritas gereja memiliki pengaruh yang sangat kuat. Hal tersebut memperlihatkan bahwa Islam pada masa itu lebih mampu berintegrasi dengan tradisi filsafat dari Barat terutama dari Yunani dibandingkan tradisi gereja. Hal ini terutama terlihat pada abad ke-8 dan 9, ketika para pemimpin Islam yang berpusat di Baghdad mulai mengambil perhatian khusus terhadap ilmu Yunani dengan memerintahkan para sarjana Islam untuk melakukan penerjemahan besar-besaran terhadap sumber-sumber dari Yunani (Ravertz, 2004: 20). Masuknya pemikiran Yunani yang semakin besar tersebut mempengaruhi perkembangan ilmu pengetahuan di dunia Islam, baik dalam bidang filsafat, matematika, astronomi, dan juga kedokteran, dengan tidak menghilangkan dasardasar fundamentalnya yaitu wahyu.

Latar epistemologis dalam filsafat Islam memiliki perbedaan yang sangat mendasar apabila dibandingkan dengan filsafat Barat. Karakteristik pemikiran Barat sangatlah teguh terhadap keberadaan pembaharuan sesuai dengan jiwa kebebasan bangsa Yunani, tetapi sekaligus rapuh karena berlandaskan pada sejarah perdebatan yang berlangsung sejak berabad-abad silam dan kemudian menghasilkan berbagai aliran pemikiran yang bersifat dialektis dan tidak pernah sampai pada suatu bentuk akhir. Beberapa contoh aliran tersebut adalah idealisme, realisme, rasionalisme, dan empirisme. Filsafat Islam sendiri memiliki keteguhan yang lebih kuat apabila dibandingkan dengan gerak perkembangan pemikiran filsafat Barat, karena aliranaliran dalam filsafat Islam berada pada lingkaran yang terus mengalami perkembangan dengan tetap mempertahankan suatu titik tumpu utamanya yang berupa unsur religiusitas. Filsafat Islam dalam hal ini memiliki dua sisi yang berbeda dengan mengandalkan metode-meto- 
de tertentu untuk membangun argumentasi rasional sekaligus berada dalam pengaruh quasi religius yang amat dominan, baik tentang apa yang dianggap sebagai kebenaran primernya, ataupun dalam pemilihan premis-premis silogismenya (Bagir, 2005: 73). Hal tersebut yang kemudian menjelaskan bahwa filsafat Islam dengan proses rasionalisasi dengan fungsi akal (al-'aql) mencoba membumikan dan mengkomunikasikan sumber-sumber keagamaan kepada nalar manusia. Suatu sikap eklektis dalam mengintegrasikan antara unsur-unsur terbaik dalam paradigma Barat dengan wahyu berupa Al-Qur'an.

\section{AWAL MULA PERKEMBANGAN FILSAFAT DALAM ISLAM}

Filsafat sebagai pintu masuk dalam perkembangan ilmu pengetahuan menjadi salah satu gerbang untuk menapaki pencarian manusia terhadap kebenaran dalam memahami realitas yang terhampar begitu luas. Akal menuntun manusia atas kesadarannya untuk mencari tahu kebenaran yang paling mendasar dan mencoba mengungkapkannya dalam alam imaginasinya. Akal manusia menjadi pusat dari kemampuan manusia untuk membentuk sistem pengetahuan yang disebut sebagai filsafat tersebut. Seperti yang telah dijelaskan sebelumnya, para pemikir dari Yunani Kuno lah yang telah menjadi perintis dari perkembangan tradisi berpikir secara radikal dan spekulatif dalam menyingkap realitas, memahami asal mula kehidupan, sebab pertama (causa prima), dan mencari the ultimate reality yang tak dapat diatasi kembali. Setelah kehancuran peradaban Yunani Kuno tersebut dan runtuhnya Imperium Romawi, namun demikian umat Islam lah yang kemudian memelihara dan mengembangkan tradisi berfilsafat. Berkat peranan umat Islam dalam pemeliharaan terhadap sumber-sumber pengetahuan dari Yunani itu lah, filsafat dapat dikenal kembali dalam dunia pemikiran Barat sampai saat ini (Ali, 1991: 4). Hal ini memperlihatkan begitu besarnya peranan dan pengaruh dari umat Islam pada masa itu terhadap perkembangan filsafat dan ilmu pengetahuan, hingga menurut Haidar Bagir (2005: 72) perkembangan pemikiran filsafat di dunia apa pun sampai saat ini tidak dapat dikatakan benar-benar lepas dari bayang-bayang pandangan dunia Islam. 
Filsafat Islam dalam keberadaannya tidaklah luput dari suatu proses historis. Pemaparan terhadap sejarah munculnya filsafat Islam sangatlah penting dilakukan untuk mengawali pembicaraan tentang perkembangan pemikiran Islam dan juga perkembangan dalam dunia keilmuannya. Memahami sejarah perkembangan filsafat Islam, dapat diawali dengan mengetahui awal mula penggunaan argumentasi rasional terhadap pembuktian keberadaan Tuhan. Hal itu diawali oleh Ali Ibn Abi Thalib dalam karyanya yang berjudul Nahj Al-Balaghah (Path of Eloquence) yang berisi tentang bukti-bukti rasional terhadap keesaan Tuhan (Nasr, 1996: 4). Karya tersebut meskipun masih berada pada ranah teologis yaitu dalam ilmu kalam, tetapi telah memperlihatkan kesadaran umat Islam sejak abad pertama keberadaan Islam atas pentingnya peranan rasio manusia dalam menyelami dan memahami ajaran Islam, sekaligus untuk melindungi dan mempertahankan Islam dengan jalan penguatan pemaknaan secara rasional. Tentunya hal tersebut tidak lepas dari pengaruh dasar ajaran Islam itu sendiri, yaitu AlQur'an. Penggunaan akal (al-'aql), dalam Al-Qur'an memiliki keutamaan tersendiri, seperti halnya yang dinyatakan dalam QS: Al-Anfaal, 22 sebagai berikut;

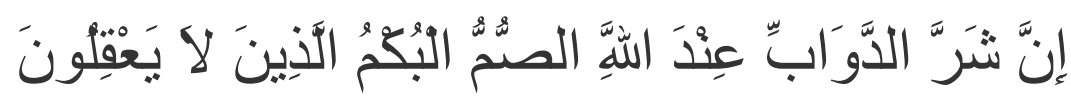

"Sesungguhnya makhluk yang seburuk-buruknya pada sisi Allah ialah; orang-orang yang pekak dan tuli, yang tidak mau menggunakan akal (alladzinna laa ya'qiluun)."

Hal tersebut menjelaskan begitu pentingnya penggunaan akal dalam ajaran Islam. Makhluk yang mampu menggunakan akalnya dianggap memiliki tingkatan yang lebih tinggi dibandingkan dengan makhluk yang tidak mau menggunakan akalnya. Akal dianggap sebagai anugerah termulia dari Tuhan untuk manusia, dan hal itu yang merupakan salah satu alasan mudahnya filsafat masuk ke dalam Islam (Black, 2006: 130). Berdasarkan hal tersebut, dapat dipahami bahwa keutamaan daripada 'aql tidak hanya terbatas karena pengaruh dari budaya Yuna- 
ni yang datang dan bercampur dengan budaya Islam, tetapi karena memang dalam Islam sendiri akal dianggap memiliki tingkatan epistemologis yang tinggi.

Perkembangan filsafat dalam Islam secara historis apabila mengambil langkah jauh ke belakang dapat dikatakan dimulai oleh pengaruh kebudayaan Hellenis, yang terjadi akibat bercampurnya budaya Timur dan kebudayaan Yunani dari Barat. Hal tersebut dimulai saat Alexander The Great atau Iskandar Agung Zulkarnain yang merupakan salah satu murid dari Aristoteles berhasil menduduki wilayah Persia pada 331 SM dan melakukan usaha perkawinan antara budaya Yunani dengan bangsa jajahannya di Timur (Ali, 1991: 5). Perkawinan kebudayaan itu-lah yang mengakibatkan munculnya benih-benih lahirnya filsafat dalam masyarakat Muslim di kemudian hari. Tetapi tidak ada peristiwa yang teramat berpengaruh atas kemunculan dan perkembangan pesat atas filsafat Islam kecuali peristiwa yang diawali pada zaman Bani Abbasiyah dari abad ke- $8 \mathrm{M}$ dan seterusnya, yaitu transmisi keilmuan Yunani Kuno ke masyarakat Islam-Arab dengan penerjemahan sumber-sumber literatur keilmuan dari Yunani ke bahasa Arab secara besar-besaran (Huff, 2003: 48). Dari peristiwa tersebut dunia pemikiran Islam semakin terfokus pada pendamaian antara filsafat dan agama ataupun akal dan wahyu, yang kemudian mempengaruhi semakin diusungnya integrasi antara akal dan wahyu sebagai landasan epistemologis yang berpengaruh pada karakter perkembangan ilmu pengetahuan dalam dunia Islam.

Penggunaan akal dianggap penting dalam memahami dan menyelesaikan berbagai permasalahan dalam aspek keagamaan pada masa awal perkembangan pemikiran Islam, yaitu untuk mempertahankan bangunan teologi dari Islam. Hal tersebut tidak dapat dipahami tanpa merujuk pada keberadaan aliran pemikiran Islam yang tertua yang telah mendasari diri pada kebutuhan pemikiran Islam atas keberadaan penalaran terhadap dalil-dalil naql, yaitu mazhab Mu'tazilah (Ali, 1991: 15). Mazhab ini dapat dikatakan sebagai salah satu aliran filsafat karena telah sedikit banyak mengalami keintiman dengan dunia filsafat dari pengaruh budaya Hellenis, tetapi sekaligus juga dapat 
dipahami sebagai mazhab sistematik dalam ilmu kalam. Mazhab ini merupakan pioneer dari pemikiran umat Muslim atas penggunaan jawaban rasional dalam membahas berbagai hal yang berkenaan dengan hukum-hukum agama, baik dalam bidang kemanusiaan, kosmologi, dan teologi. Bidang tersebut termuat dalam lima prinsip dasar, yaitu: keesaan (al-tawhid) yang menggeser pemahaman atas sifat-sifat Ilahiah ke esensi Ilahi; keadilan ( $a$ l-adl) yang menyatakan manusia sebagai ciptaan mampu melakukan proses transcendence dengan kemerdekaannya; janji dan ancaman ( $\left.a l-w a^{\prime} d w a^{\prime} l-w a^{\prime} i d\right)$; posisi Muslim dan perbuatan dosa (al-manzilah bayn al manzila tayn); dan anjuran manusia berbuat baik (al-amr bi'l ma'ruf wa 'l-nahy 'an al-munkar) (Nasr, 1996: 7,8,9). Argumentasi rasional dari mazhab ini menyematkan suatu pandangan tentang kehendak bebas manusia, bahwa manusia-lah yang mampu memilih atas apa yang akan ditindakkannya, dan perhitungan dalam hisab dilakukan berdasarkan tindakannya tersebut.

Penerjemahan hasil keilmuan dari Yunani dan budaya lainnya termasuk India ke dalam bahasa Arab telah membawa zaman keemasan dunia Islam (The Golden Era). Hal tersebut sekaligus memperlihatkan begitu tolerannya umat Muslim terhadap berbagai pandangan yang berkembang saat itu, baik dari para penganut keyakinan monoteis lainnya, seperti kaum Yahudi yang mendapat posisi tinggi saat itu di negeri-negeri Islam (Ravertz, 2004: 20), hingga kaum Pagan, yang terbukti dari ketertarikan umat Muslim terhadap literatur bangsa Yunani Kuno yang notabene adalah penyembah bintang dan berhala. Keterbukaan umat Islam terhadap hasil ilmu pengetahuan dari budaya lain inilah yang telah banyak membawa pengaruh yang begitu besar terhadap perkembangan filsafat dan ilmu pengetahuan. Kondisi tersebut memunculkan semakin banyaknya cabang-cabang keilmuan dalam dunia Islam, yang tidak hanya bersifat teosentris dengan merujuk pada dalil-dalil Al-Qur'an dan Al-Hadits sebagai sumber kebenarannya oleh para Mutakalim (ahli kalam), tetapi juga bersifat antroposentris dengan rasio dan pengalaman empiris manusia sebagai landasannya tanpa menegasikan dalil dalam Al-Qur'an dan Al-Hadits. 


\section{PENGERTIAN ILMU DI DUNIA BARAT DAN ISLAM}

Pemahaman terhadap ilmu dalam filsafat Islam sangatlah penting untuk dipahami lebih mendalam, mengingat dunia Islam pernah menjadi salah satu pusat dari perkembangan ilmu pengetahuan. Guna mengkaji lebih jauh pemahaman ilmu dalam filsafat Islam, tentu perlu dipahami lebih dahulu pemaknaan dan batas-batasan dari ilmu, agar tidak melebar ke dalam konteks yang lebih luas. Ilmu berasal dari istilah 'alima dalam bahasa Arab yang berarti tahu (Anshari, 1987: 47). Dapat dipahami bahwa secara terminologi ilmu merupakan suatu kondisi yang hanya dapat ditemui pada mahkluk yang berpikir, yaitu manusia. Proses mengetahui adalah salah satu karakter yang tidak dapat dilepaskan dari diri manusia dalam memenuhi rasa keingintahuannya (curiousity) terhadap dunia.

Ilmu adalah salah satu penanda terhadap keberadaan umat manusia, dan setidaknya terdapat tiga alasan mengapa manusia melalui jalan scientific (keilmuan): (1) human not ready yet lived in the "first world" which had meaning pure nature without civilization, (2) human beings are creature who dissatisfied to what they have done or achieved, (3) Human has immaterial and psychically questions about meaning which required answers (Zubair, 2013: 2,3 5). Tidaklah dapat disangkal bahwa ilmu akan selalu memiliki keterikatan dengan keberadaan umat manusia. Ilmu hadir karena pengaruh kondisi eksistensial dari manusia, yang merupakan makhluk berpikir yang mampu melakukan pertimbangan dan memiliki kesadaran akan kebutuhan dirinya atas keterhubungannya dengan dunia.

Ilmu sebagai aktivitas mengetahui memperlihatkan ilmu merupakan suatu proses yang terarah kepada tujuan tertentu, yaitu pemahaman dan pengetahuan. Dalam hal ini ilmu tidak dapat dilepaskan dengan keberadaan metodologi dalam pencapaian pengetahuan. Metodologi dalam hal ini harus dipahami sebagai perspektif dalam memahami objek ilmu, sehingga fakta dapat ditata sesuai karakteristiknya berdasar mind mapping tertentu (Zubaidi, 2013: 23). Metodologi sebagai kerangka pikir dan sudut pandang dalam kegiatan scientific akan menentukan alat epistemologis serta hasil pengetahuan yang 
didapatkan. Alat epistemologis yang digunakan dalam proses mengetahui tersebut juga kemudian mempengaruhi penggunaan metode apa saja yang relevan.

Sebagaimana yang dijelaskan oleh Ravertz (2004: 127), dalam kegiatan keilmuan seorang praktisi keilmuan tidak bertugas sekedar mendeskripsikan dunia seperti yang telah ditemukan, tetapi dirinya mencoba untuk menghasilkan suatu gambaran atas kerja dunia agar mampu dipahami dengan menggunakan kerangka teoritis tertentu. Seorang ilmuan bukanlah seorang photographer yang mengambil hasil potret dari dunia, tetapi lebih jauh, mencoba merumuskan gerak dan kerja dunia dengan bertumpu pada teori tertentu. Landasan teoritis tersebutlah yang apabila mengambil istilah dari Thomas Kuhn sebagai paradigma keilmuan yang merupakan perpaduan dari metode dan teori yang bersama-sama mewujudkan sesuatu yang mendekati pandangan dunia (Sofyan, 2010: 162). Dan dengan paradigma dan karakteristiknya tersebut yang kemudian mengikat praktik ilmiah dengan aturan dan standar metodenya. Dengan kata lain membicarakan masalah ilmu akan seringkali terkait dengan perbincangan mengenai meto-dologi yang digunakan.

Ilmu kerap dikatakan bersifat antroposentris, yang menempatkan kebenaran pada penalaran dan pengalaman manusia. Ilmu yang dipahami berimpitan dengan metodologinya, bagaimanapun akan selalu memiliki kedekatan dengan landasan filosofis sebagai penunjuk arah dalam aktivitas ilmiah. Hal tersebut dikarenakan kelahiran ilmu (science) tidaklah dapat terlepas dari keberadaan filsafat, sebagaimana menurut Van Melsen: “... the first attempt to understand nature could not be scientific, but had to be chiefly philosophical " (Melsen, 1961: 55). Manusia, dalam usaha memahami kerja alam, tidaklah mampu benar-benar terbatas pada praktik scientific, tetapi melibatkan penalaran filosofis dengan mengemukakan asumsi-asumsi dasar yang berasal dari ideide apriori yang dihubungkan dengan pengalaman yang didapat. Hal tersebut, akan tetapi mengalami pergeseran saat mulai suburnya ruh positivisme yang menjadi semangat baru dalam dunia keilmuan modern di Barat, memunculkan pemahaman baru bahwa bukan ide- 
ide apriori dalam landasan teoritis pada aktivitas ilmiah yang menjadi tolok ukur keilmuan, tetapi dunia keilmuan bergeser dengan terfokuskan pada hal-hal fisik yang mampu diukur dan dibuktikan secara empiris.

Kondisi tersebutlah yang kemudian lambat laun memisahkan ilmu dari induknya, yaitu filsafat. Membicarakan definisi ilmu di dunia Barat tentu saja akan berkutat pada hal tersebut, karena science dan knowledge adalah hal yang dianggap berbeda, science (ilmu pengetahuan) berhubungan dengan ilmu fisik, bersifat eksperimental karena diverifikasi melalui eksperimen (Snijders, 2009: 19), sedangkan knowledge (pengetahuan) berkaitan dengan bidang baik fisik maupun metafisik. Dapat dikatakan apabila menggunakan definisi Barat, pengetahuan memiliki cakupan yang lebih luas, karena ilmu terbatas pada objek dalam dunia fisik dan bersifat verifikatif dengan pembuktian secara empiris melalui eksperimen. Ilmu, di dunia Islam sendiri, memiliki status yang berbeda apabila dibandingkan dengan apa yang terjadi di Barat. Hal tersebut dikarenakan ilmu dalam tradisi pemikiran Islam tidak pernah mengalami tarik ulur antara akal dan landasan epistemologis berupa wahyu seperti pada abad pertengahan yang diiukti masa Renaissance di Barat (Syarif dalam Husaini, 2013: 60).

Wahyu dalam Islam menjadi sumber kebenaran, dan dalam dunia keilmuan kaum Mutakallimun dengan ilmu kalam membuktikan bahwa Islam bukanlah antithesis dari ilmu, untuk mempertahankan bangunan teologis dari Islam. Filsuf Islam pun sejak abad ke-8 M mencoba melakukan integrasi antara sumber-sumber ilmu dari Yunani untuk diabsahkan tidak menegasi norma agama. Berdasarkan uraian tersebut terdapat perbedaan besar antara pandangan tentang ilmu dalam tradisi Barat yang semakin memisahkan diri dengan bidang mental berupa keyakinan, kepercayaan, dan metafisika, dengan ilmu dalam pandangan Islam yang tetap mempertahankan dasar epistemologis utamanya yang berupa wahyu Ilahi yang turun pada nabi. Tidak dapat dipungkiri bahwa ilmu untuk dapat berkembang dan membongkar pengetahuan dunia harus memiliki kebebasan, tetapi dalam pemikiran Islam netralitas ilmu terhadap nilai dibatasi pada ranah 
metafisika keilmuan, dan epistemologi, sedangkan dalam penggunaannya (aksiologi) harus dilandasi oleh asas-asas moral, termasuk dalam hal ini norma moral dalam agama yang bersumber dari wahyu (Sofyan, 2010: 203). Perkembangan ilmu dalam tradisi Islam dengan kata lain tidak dapat terlepaskan dari keberadaan wahyu sebagai landasan normatif dan epistemologis.

\section{ALIRAN-ALIRAN DALAM FILSAFAT ISLAM}

Setiap aktivitas keilmuan memiliki objek, metode, sistem, dan tingkat kebenaran yang berbeda-beda, baik dari segi sudut pandang maupun dari segi metode (Suhartono, 2008: 118). Hal tersebut juga nampak dalam perkembangan pemahaman ilmu dalam tradisi pemikiran Islam. Pemahaman ilmu dalam filsafat Islam membutuhkan suatu pemetakan yang mampu menggambarkan kerangka perkembangan pemikiran dalam dunia Islam baik objek, metode, maupun sistem validitasnya. Hal tersebut dikarenakan dalam filsafat Islam realitas yang diakui sebagai sumber ilmu tidak hanya terbatas pada realitas fisik, tetapi juga realitas yang bersifat nonfisik, baik berupa realitas mental maupun realitas metafisik murni (Kartanegara, 2002: 58). Pemetakan tersebut dapat dilakukan dengan berlandaskan pada aliran-aliran pemikiran dalam sejarah tradisi pemikiran Islam dan metode yang digunakannya.

Perkembangan aliran pemikiran dalam tradisi Islam secara historis, dan pembedaan muatan kajiannya, terbagi setidaknya menjadi dua fase besar, yaitu fase penguatan bangunan teologis dalam Islam dan fase integrasi tradisi pemikiran Yunani Kuno dengan Islam. Keduanya merupakan fase ketika ilmu mulai mengalami perkembangan dalam dunia Islam. Pada fase pertama, yang memiliki peranan utama adalah kaum muttakalimun yang menyebarkan ilmu kalam untuk memberi bukti dan menghalau keraguan terhadap agama (Nasr, 1995: 4). Ilmu kalam berbeda halnya dengan teologi di dunia Barat yang dipisahkan pada luar bidang keilmuan. Ilmu kalam dalam dunia Islam dipahami juga sebagai cabang keilmuan yang berpegang pada pembuktian melalui argumentasi rasional bahwa wahyu tidak berlawanan dengan per- 
kembangan ilmu pengetahuan, dan merupakan usaha penyelesaian masalah keagamaan. Hal tersebut terutama diakibatkan oleh munculnya perdebatan teologis yang terjadi karena perbedaan pendapat dan perpecahan dari umat Islam. Kondisi ini yang kemudian menimbulkan berbagai macam sudut pandang dalam penafsiran terhadap Al-Qur'an dan Hadits dari berbagai macam golongan (Sofyan, 2010: 39), beberapa golongan tersebut akan dijelaskan pada uraian berikutnya.

\section{Kaum Khawarij dan Kaum Murji'ah}

Kaum Khawarij ini pada dasarnya adalah golongan yang muncul akibat dari peristiwa politik, bukan atas dasar tujuan keilmuan, tetapi pandangannya telah memicu perdebatan dari para ulama Islam dari berbagai golongan dan penguatan ilmu kalam. Kaum Khawarij merupakan pecahan dari golongan Syi'ah pendukung Khalifah Ali, yang telah membelot memisahkan diri akibat terjadinya perbedaan pendapat dalam pelaksanaan arbitrase dalam hubungan politik dengan golongan Mu'awiyah (Nasution, 1986: 11). Kaum Khawarij memiliki asumsi teologis berkenaan tentang persoalan dosa besar oleh kaum mukmin. Kaum Khawarij, dengan menggunakan nash Al-Qur'an dan Hadits, melontarkan pendapatnya yang menjadi reaksi akibat terjadinya pertumpahan darah golongan pengikut Ali dengan golongan Mu'awiyah atas dasar tujuan kekuasaan.

Kaum Khawarij berpendapat bahwasanya dosa besar apabila seorang mukmin yang melakukan dosa dan sebelumnya telah mengetahuinya, dan mereka adalah kaum yang telah keluar dari umat atau dapat dikatakan murtad (Black, 2006: 49). Dari pendapat tersebut dapat dipahami bahwa kaum Khawarij adalah golongan yang bersifat keras terhadap apa yang dianggap sebagai benar ataupun salah (dosa). Bagi kaum Khawarij setiap orang yang tidak berhijrah kepada golongan mereka adalah musyrik (Sofyan, 2010: 41). Pandangan ini mengedepankan suatu sikap fanatisme yang berpandangan bahwa kebenaran pengetahuan bersifat tunggal, dan kebenaran tersebut berada pada pemahaman mereka. Dari pendapat tersebut, muncul reaksi dari golongan yang tidak sependapat yaitu dari kaum Murji'ah. Kaum Murji'ah ini mengutamakan persatuan umat Islam dan mencegah perpecah- 
an dalam umat muslim dengan berpendapat bahwa seorang pendosa pun tetaplah seorang muslim (Black, 2006: 48). Kaum Murji'ah dalam hal ini berusaha menjernihkan dengan berpandangan bahwa hukum sepenuhnya adalah kuasa Tuhan, ketetapan pelaku dosa besar tidak dapat ditentukan oleh manusia. Kedua golongan ini merupakan awal mula dari perdebatan dalam ilmu kalam, yang kemudian akan dilanjutkan dengan berbagai Mazhab, termasuk yang berada pada masa kekuasaan Bani Abbasiyah.

\section{Mazhab Mu'tazilah}

Mazhab Mu'tazilah didirikan oleh Washil bin Atha dan merupakan mazhab pertama dalam ilmu kalam yang menempatkan pandangan rasional dalam memahami nash Al-Qur-an dan Al-Hadits (Nasr, 1996: 6). Golongan ini juga menjadi salah satu reaksi dari munculnya perdebatan tentang dosa besar oleh kaum mukmin yang telah disulut oleh kaum Khawarij. Mazhab ini, dalam upaya menanggapi hal tersebut, mengambil jalan tengah dengan berpendapat bahwa orang yang berada di antara mukmin dan kafir tidaklah dapat dikatakan sebagai mukmin lagi namun juga tidak pula jatuh menjadi kafir ataupun murtad tetapi disebut menjadi golongan fasiq (Ali, 1991: 15), orang yang berdosa. Mazhab Mu'tazilah, karena pandangan tersebut, mampu menjadi penengah dalam perdebatan tersebut, dan kemudian pandangannya diterima oleh umat muslim saat itu meskipun dalam perkembangannya bermunculan golongan yang memiliki contra perception terhadap pandangan Mu'tazilah. Diterimanya mazhab ini secara luas terlihat pada masa kepemimpinan Khalifah Al-Makmun dari Bani Abbasiyah. Hal tersebut nampak karena beberapa orang Mu'tazilah mendapatkan kedudukan dalam pemerintahan, dan terutama saat pandangan Mu'tazilah tentang keterciptaan Al-Qur'an dijadikan sebagai doktrin resmi negara (Black, 2006: 68).

Mazhab ini dalam dunia keilmuan, berusaha untuk menghindari pandangan yang bersifat antroposentris meskipun pada dasarnya kaum ini menggunakan asumsi rasional dalam membentuk bangunan teologi. Mazhab ini berpendapat bahwa manusia memiliki keterbatasan dalam memahami sifat-sifat Ilahi, baik pendengaran atau penglihat- 
an, dan setiap sifat Ilahi tidak memiliki kenyataan (Nasr, 1996: 8). Pandangan tersebut menggeser pemahaman tentang sifat-sifat Ilahi lebih kepada esensi Ilahi. Mazhab ini pada masa kepemimpinan dari Bani Abbasiyah turut ambil bagian dalam mengkaji dan mendalami dunia filsafat yang hadir dari Yunani, dan dari hal tersebut kemudian bermunculan tokoh-tokoh filsuf Islam dari mazhab ini termasuk yang dikatakan sebagai filsuf Islam pertama yaitu Al-Kindi, yang lebih menitikberatkan 'aql sebagai landasan utama dalam memecahkan permasalahan, dan naql digunakan setelahnya (Ali, 1991: 16). Dapat dikatakan bahwa dari aliran-aliran ilmu kalam yang ada, mazhab inilah yang lebih mengambil perhatian khusus terhadap fungsi akal pikiran manusia dalam memecahkan permasalahan baik dalam hubungan manusia dengan Tuhan, bidang etika dalam lingkungan sosial, maupun perdebatan dalam bidang kosmologi.

\section{Mazhab Asy'ariah}

Pada dasarnya mazhab Mu'tazilah sangatlah diterima pada masa kepemimpinan bani Abbasiyah dan memiliki kesempatan besar dalam mengembangkan mazhabnya. Hal tersebut, namun demikian tidaklah menutup kemungkinan timbulnya paham lain yang memiliki pendapat yang berlawanan dengan mazhab Mu'tazilah. Abu 'I-Hasan al'Asy'ari adalah tokoh yang mencoba mengkritisi apa yang terjadi pada mazhab Mu'tazilah tersebut, dengan mendirikan ajaran teologi baru yang tersebar di lingkungan Islam Sunni (Nasr, 1996: 11). 'Asy'ari, dengan semangat untuk kembali pada kemurnian ajaran-ajaran Al-Qur'an, berusaha melawan bukti-bukti rasional yang menjadi landasan pikir Mu'tazilah dengan membangun mazhab barunya yang dinamakan Asy'ariyah.

Mazhab Asy'ariyah ini berpendapat bahwa perbuatan manusia adalah ciptaan Tuhan seluruhnya (Nasution, 1986: 71). Pandangan tersebut merupakan usaha kaum para pengikut Asy'ariyah untuk menundukkan akal terhadap wahyu, dan menolak keberadaan kehendak bebas manusia, dalam hal ini pandangan Asy'riyan seringkali dihadapkan dengan suatu sikap fatalistik. Segala yang terjadi di alam, termasuk perbuatan manusia, bukanlah atas dasar suatu hukum sebab-aki- 
bat, tetapi karena kehendak dari Tuhan. Mazhab ini berpendapat bahwa baik buruknya suatu hal haruslah berdasarkan dengan wahyu, dan hal tersebut membedakannya dengan Mu'tazilah (Rozak, 2012: 149). Asy'ariyah, dalam bidang etika mendasarkan pada wahyu yang murni, dalam arti keberadaan Al-Qur'an dianggap abadi karena terdapat kekuasaan Tuhan di belakangnya. Pandangan Asy'ariyah ini dalam dunia keilmuan bertitik tolak pada pandangan bahwa segala sesuatu disusun dari atom (juz'la yatajaza) yang terbentuk dalam ruang yang tidak kontinu, dan terbentuk oleh dasar kehendak dari Tuhan (Nasr, 1996: 14). Asy'ariyah, dalam hal ini menolak keberadaan hukum kausalitas yang berdasarkan pada hubungan sebab akibat, mazhab ini berpandangan bahwa Tuhan sebagai Kuasa Mutlak yang berkehendak atas seluruh gerak kehidupan di dunia.

\section{ALIRAN DALAM FILSAFAT ISLAM DAN PEMAHAMANNYA TERHADAP ILMU}

Istilah falsafat (filsafat) muncul dan mulai berkembang saat banyaknya terjadi penerjemahan literatur Yunani ke bahasa Arab yang dimulai pada abad ke $8 \mathrm{M}$ saat kepemimpinan Bani Abbasiyah. Dari peristiwa itu filsafat Islam berkembang dengan bermunculannya para filsuf muslim dengan berbagai macam aliran pemikiran. Filsafat Islam dapat dipahami sebagai suatu komponen penting pada tradisi intelek Islam. Hal tersebut disebabkan karena filsafat Islam tidak hanya telah memberi pengaruh dalam perkembangan kalam, tetapi sebagaimana ilmu-ilmu Islam seperti matematika, astronomi, medis, yang juga dapat diberi inspirasi dari filsafat Islam (Nasr, 1996: 31, 32). Aliran dalam filsafat Islam sedikitnya terbagi menjadi tiga aliran besar yaitu aliran Paripatetik (Hikmah Masya'iyah); aliran iluminasi (Hikmah Israqiyah), dan aliran Hikmah Muta'aliyah sebagai sintesisnya.

\section{Ilmu dalam Aliran Paripatetik (Hikmah Masya'iyah)}

Aliran Paripatetik sangatlah concern terhadap perbincangan epistemologi dalam memahami sumber daripada kebenaran pengetahuan manusia dengan banyak mendapatkan pengaruh dari pemikiran Aristoteles dan Neo-Platonis. Metode yang digunakan oleh aliran ini untuk 
menetapkan kebenaran adalah melalui metode Burhani, suatu penarikan kesimpulan dengan menunjukan hubungan antara premis mayor dengan premis minor sehingga menghasilkan konklusi yang logis dan rasional (Jabiri, 1993: 383). Nama Paripatetik tersebut berasal dari istilah Yunani yaitu paripatatos, yang berarti berjalan berbolak-balik. Istilah paripatatos tersebut merujuk pada kebiasaan Plato dalam mengajarkan filsafat pada muridnya dengan berjalan berbolak balik (Bagir, 2005: 85). Hal tersebut memperlihatkan begitu besarnya pengaruh tradisi Yunani dalam aliran filsafat ini. Beberapa tokoh dalam aliran ini antara lain:

\section{Al-Kindi}

Al-Kindi adalah tokoh yang telah mengawali pemikiran dalam aliran Paripatetik. Al-Kindi seringkali dikatakan sebagai filsuf pertama dalam tradisi pemikiran Islam, karena dirinya telah berhasil memadukan antara agama dengan filsafat, wahyu dengan akal. Al-Kindi, dalam hubungannya dengan ilmu, membagi ilmu menjadi tiga macam, yaitu ilmu fisika yang berkaitan dengan berbagai hal yang dapat ditangkap dengan panca indera, ilmu matematika yang terdiri atas ilmu hitung, astronomi, teknik, dan musik, kemudian ilmu ketuhanan (al-rububiyah) yang memiliki tingkat paling tinggi dan tidak berkaitan dengan benda (Hanafi, 1976: 27). Dalam hal ini memperlihatkan bahwa dalam pandangan Al-Kindi, ilmu tidak hanya terbatas pada hal yang fisik dan mampu dihitung atau diukur, tetapi ilmu juga dapat berkaitan dengan aspek metafisis yang tak mampu digapai oleh panca indera manusia, seperti halnya dengan ilmu ketuhanan tersebut, dan dianggap memiliki tingkatan tertinggi.

Karya utama dari Al-Kindi adalah Al-Falsafah Al-Ula (The First Philosophy), dalam karya tersebut Al-Kindi berusaha memberikan asumsi dasar bahwa filsafat dan agama tidak berlawanan, melainkan "filsafat pertama" (metafisika) dengan teologi sesungguhnya mengarah pada hal yang sama yaitu pemahaman tentang Tuhan (Bagir, 2005: 94). Dapat dipahami dari hal tersebut bahwa Al-Kindi mencoba membangun harmoni baru antara pengetahuan Ilahi dengan pengetahuan yang diperoleh dari penalaran dan pengalaman. 


\section{Al-Farabi}

Aliran paripatetik ini kemudian dilanjutkan oleh Abu Nasr Muhammad Al-Farabi. Al-Farabi adalah salah satu pemikir Islam yang tidak hanya telah mengintegrasikan filsafat dengan agama, tetapi juga telah mampu meletakkan dasar-dasar dalam bangunan filsafat dalam dunia Islam. Dan karena hal tersebut Al-Farabi disebut sebagai AlMu'allimuts-Tsani (guru kedua) setelah Aristoteles (Ali, 1991: 40). Hal ini memperlihatkan besarnya nama Al-Farabi dan pengaruhnya terhadap perkembangan filsafat dan ilmu dalam dunia Islam. Menurut AlFarabi, filsafat hadir lebih dahulu daripada agama, karena semua kebenaran agama harus dipahami dan dinyatakan pada mulanya melalui cara-cara rasional sebelum kebenaran itu diambil Nabi (Abdullah, 1995: 151). Hal tersebut menjelaskan bahwa Al-Farabi menaruh pemahamannya terhadap filsafat secara lebih luas sebagai penggunaan akal. Al-Farabi, dalam hal ini ingin menghantarkan pengertian filsafat sebagai salah satu ciri mutlak dari kemanusiaan. Akal dipahami sebagai daya berpikir yang memungkinkan manusia memahami berbagai pengertian, sehingga dapat membedakan yang mulia dari yang hina serta menguasai seni dan ilmu (Hamdi, 2004: 77).

Al-Farabi memiliki pandangan yang begitu luas dan terpengaruh tidak hanya oleh salah satu tokoh saja. Pemikirannya dapat dikatakan sebagai suatu pemikiran hasil dari sinkretisme dari berbagai pemikiran. Hal tersebut nampak misalnya dalam teori negara Al-Farabi banyak terpengaruh dengan Plato, metafisika terpengaruh dengan Aristoteles, dan mengenai emanasi dirinya terpengaruh oleh Plotinos, yang semuanya akan disesuaikan dengan ajaran Islam (Ali, 1991: 42). Hal tersebut merupakan salah satu usahanya untuk mendamaikan setiap paham pemikiran agar mampu digunakan pada bidang-bidang yang menurutnya lebih relevan.

Al-Farabi membedakan ilmu menjadi dua macam, yaitu ilmu dengan konsepsi tasawwur mutlak dan konsep yang disertai pikiran (judgement-tasdiq) (Sofyan, 2010: 326). Ilmu dengan konsepsi tasawwur tersebut berkaitan dengan pengetahuan yang mampu dipahami secara langsung lewat pengalaman inderawi, sedangkan ilmu yang disertai pikiran merupakan ilmu yang berada pada tingkatan lebih tinggi, dan 
hanya mampu dipahami dengan proses yang terjadi pada akal. AlFarabi membagi akal manusia menjadi 3 tingkatan (Ali, 1991: 49), yaitu:

a. Akal Potensial (al-aqlul-Hayulani) yang mempunyai daya tanggap melalui panca indera, dalam arti melepaskan bentuk dari materinya.

b. Akal Aktual (Al-Aqlu bil-fi'li) yang dapat menangkap arti dari sesuatu serta melepaskan dari materi, sehingga berwujud dalam akal.

c. Akal Intelek (Al-aqlul-Mustafadh) yang dapat menangkap bentuk semata-mata tanpa dikaitkan dengan materi atau sanggup menangkap inspirasi dari akal $f a^{\prime} a l$ yang merupakan pancaran terendah dari Akal Pertama (Tuhan).

Proses mencapai kebenaran pengetahuan adalah suatu proses abstraksi, yaitu proses yang terjadi dalam setiap tahap akal, dari akal potensial yang sejak awal untuk memikirkan alam materi, kemudian perubahannya menjadi akal aktual menjadikan manusia mampu mendapatkan pengetahuan tentang pengertian-pengertian atau berbagai konsep. Proses tersebut terjadi akibat pengaruh dari keberadaan akal $f a^{\prime} a l$ yang merupakan tingkatan terendah dari sepuluh tingkatan akal yang berasal dari pancaran Tuhan, dan menjadikan manusia mampu melakukan abstraksi dari pengalaman inderawi kemudian menyerapnya dan mengalami proses mengingat menjadi suatu konsep-konsep universal dalam akal intelek. Pada dasarnya pandangan ini bertitik tolak pada pentingnya kerja akal dalam tercapainya pengetahuan manusia, tetapi ikut melibatkan jalan yang bersifat sufistik (Bagir, 2005: 106), yaitu dengan pelatihan/ riyadah untuk melakukan interaksi dengan akal kesepuluh dalam proses mencapai kebenaran pengetahuan.

\section{Ibn Sina (Avicenna)}

Aliran paripatetik mencapai puncaknya pada pemikiran Ibn Sina. Asy-Syaikh Ar-Ras Abu Ali Al-Husain bin Abdullah bin Sina atau sering disebut sebagai Avicenna, merupakan filsuf sekaligus seorang ahli di bidang kedokteran yang berasal dari Persia. Pemikirannya cukup sulit untuk dibedakan dengan pemikiran dari Al-Farabi, terutama dalam hal emanasi. Hal tersebut disebabkan karena Ibn Sina memiliki 
pengaruh dari tokoh-tokoh yang sama dengan Al-Farabi yaitu Aristoteles, Plato, dan terutama Plotinos. Pengakuan terhadap Al-Farabi sebagai "guru kedua" setelah Aristoteles juga pernah muncul darinya (Ali, 1991: 40), dan dapat dikatakan hal itulah yang menjelaskan kedekatan antara pemikiran Al-Farabi dengan Ibn Sina.

Ibn Sina dalam bidang epistemologi memberikan pemahaman tentang daya dalam diri manusia untuk mencapai pengetahuan tertinggi yaitu dengan akal teoritis, yang dibagi menjadi: akal materiil (al'aql al-hayulani) yang merupakan potensi; akal bakat (al-'aql bi al-malakah) akal yang telah mulai dilatih dalam melakukan abstraksi; akal aktuil (al-'aql bi al-fi'l) yang telah dapat lebih mudah berpikir tentang halhal abstrak; dan akal perolehan (al-'aql al mustafad) yang di dalamnya arti-arti abstrak tersebut tersedia (Nasution, 1992: 36, 37). Ibn Sina memahami bahwa akal dalam melakukan refleksi filosofis (burhani) merupakan satu-satunya sarana manusia dalam mencapai kebenaran ilmu, termasuk dalam menangkap pancaran nur Akal Mutlak (Tuhan). Tuhan memiliki posisi sebagai Wajibul-Wujud dan akal murni yang merupakan penggerak pertama yang menggerakkan secara total segala yang bekerja, bukan sebagai pencipta (Durant, 1961: 71. 72). Hal tersebut terkait dengan proses emanasi, yaitu proses ketika Tuhan sebagai Penggerak Pertama memancarkan akal pertamanya dengan hierarkihierarkinya sampai dengan akal fa'al yang memancarkan segala yang ada di bumi.

Akal ditempatkan pada posisi utama dalam proses emanasi tersebut dengan pancaran-pancaran dari yang tertinggi (Tuhan) melampaui wujud-wujud immaterial dan kemudian sampai pada wujud terendah (Bagir, 2005: 105). Segala sesuatu yang ada di dunia adalah hasil dari pancaran akal murni dari Tuhan yang merupakan Wajibul Wujud, esensi yang pasti memiliki wujud pada dirinya. Akal-lah yang menuntun manusia untuk sampai pada pengetahuan tertinggi. Proses tersebut seperti halnya pandangan Al-Farabi, yang menganggap bahwa akal $f a^{\prime} a l$ ( $A l^{\prime} a q l$ al-fa'al)/ akal kesepuluh bertugas mengaktualisasikan akal manusia dan kemudian memberikan ilmu pengetahuan pada manusia, melalui suatu proses abstraksi. Ibn Sina dalam hal ini mengemukakan teori al-Rūh al-Muqaddas (ruh yang disucikan), yakni jiwa insani 
yang merupakan fakultas rasional yang dipersiapkan dari keterjagaan dan berhubungan dengan akal universal, dan kebutuhannya dicukupi dengan ilhām dan wahyu (Sina, 2009: 167,168). Akal pada dasarnya berada pada potensi, dan akan mampu berubah menjadi aktual apabila mengalami pencerahan (ilham) dan digerakkan oleh akal $f a^{\prime} a l$.

Ibn Sina membagi ilmu menjadi dua, yaitu ilmu yang kekal (hikmah) yang dipandang sebagai sebuah alat yaitu logika dan ilmu yang tak kekal (Jalaluddin, 1996: 136-138). Menurut Ibn Sina, logika merupakan alat mencapai pengetahuan dalam mencari hakikat dan fakta. Hal tersebut berbeda apabila dibandingkan dengan kaum Stoic yang menganggap bahwa logika merupakan bagian dari filsafat. Pemikiran Ibn Sina memperlihatkan bahwa antara filsafat dan spiritual tidaklah dapat dipisahkan. Dirinya menghantarkan pada suatu sistem filsafat yang disebut sebagai al hikmah al-masyriqiyyah (filsafat Timur) yang hadir bukan karena berasal dari wilayah Timur, tetapi karena filsafat ini didasarkan pada iluminasi jiwa, pencerahan rasio, dan petunjuk berupa wahyu (Nasr, 1996: 39). Suatu bentuk sintesis dari berbagai pemikiran Timur yang kemudian mempengaruhi perkembangan pemikiran dalam tradisi Islam selanjutnya, termasuk ajaran iluminasi dari Suhrawardi.

\section{Ilmu dalam Aliran Illuminasi (Hikmah Israqiyah)}

Aliran illuminasi (al-isyraq) didirikan oleh Syaik Al-Isyraq, Syihab Al-Din Suhrawardi. Suhrawadi adalah seorang mistikus dan filsuf besar yang akrab dengan filsafat perennial Islam, yang disebut al-himat al-atiqah, philosophia priscoriusm yang dirujuk sejumlah filsuf Renaissance, yang permulaannya dianggap bersifat Ilahiyah (Nasr, 1996: 69). Hikmah Israqiyah merupakan aliran yang lahir karena paham tersebut. Selain itu Israqiyah juga menjadi reaksi terhadap aliran paripatetik yang lebih mengutamakan eksistensi dibandingkan esensi. Suhrawardi mengkritik Al-Farabi dan Ibn Sina dengan menyatakan bahwa para sufi abad ketiga dan keempat Hijriah, seperti Abu Yazid al-Busami, alHallaj, dan al-Kharqani, yang merupakan para illuminasionis Persi yang asli (Taftazani, 2003: 195). 
Pengalaman spiritual dalam aliran Israqiyah mendapatkan tempat sebagai salah satu sumber dari pengetahuan. Seperti halnya pada pemikiran emanasi dari Al-Farabi dan Ibn Sina, dalam pemikiran Suhrawardi pada aliran Israqiyah pengalaman spiritual/ pengalaman intuitif merupakan sumber dari kebenaran yang hadir seperti kilat, dipahami sebagai suatu arus cahaya yang kemudian membentuk suatu pemahaman tertentu, dan proses tersebut ditempuh melalui beberapa tahapan, yaitu: (1) pembebasan dari kecenderungan duniawi dan perangkap jasmani untuk menerima pengalaman Ilahi; (2) memasuki tahapan illuminasi, dengan menemui cahaya ilham (al-anwar al-Sanihah); (3) tahap pembangunan sistem kebenaran dengan logika diskursif; (4) pengungkapan/ penulisan (Bagir, 2005: 139). Aliran ini memberikan ruang untuk pencapaian kebenaran melalui pengalaman spiritual (intuisi) dengan menggabungkannya dengan logika diskursif sebagi alat verifikasinya. Hal tersebut menjelaskan bahwa Suhrawardi bukanlah sufisme murni.

Aliran ini memberikan posisi terpenting terhadap esensi dibandingkan eksistensi yang bersifat sekunder, esensilah yang primer dan fundamental dari suatu realitas (Mazhar dalam Fazlur Rahman, 2000: $\mathrm{xv})$. Suhrawardi berpendapat bahwa dalam mengetahui sesuatu hal, manusia mengalami pengalaman tentang hal tersebut. Sebuah wujud dapat dipikirkan tanpa mengetahui keberadaannya pada entitas partikular manapun, wujud dalam hal ini dapat dikatakan identik dengan esensi. Menurutnya, pencahayaan (ilham) merupakan cara manusia untuk memahami hubungan manusia dengan Tuhan, cahaya di atas cahaya, dan makhluknya (Labib, 2005: 38). Prinsip pencapaian pengetahuan dari aliran illuminasi ini memiliki kaitan juga dengan prinsip emanasi yang dikemukakan oleh Al-Farabi dan Ibn Sina yang telah banyak mendapatkan pengaruh dari pemikiran Yunani, yang dianggap Suhrawardi tidak dapat lagi dikatakan mewakili filsafat Timur. Bagi Suhrawardi, Timur bukan soal wilayah suatu pemikiran tersebut muncul, tapi Timur merupakan awal mula cahaya.

Suhrawardi memahami bahwa filsafat Timur adalah berkaitan dengan persoalan pencahayaan dalam proses mistik. Pencapaian ultimate reality yang merupakan puncak tertinggi pengetahuan yang terda- 
lam dipahami melalui pelatihan (riyadah) untuk menangkap intuisi $($ irfān $\bar{\imath})$. Aliran ini menghendaki suatu proses mistisisme dalam memahami kebenaran serta dalam mencapai cahaya Ilahi. Filsafat Israqiyah ini identik dengan istilah filsafat cahaya, karena beranggapan bahwa wujud memiliki hierarki-hierarki, yang dalam paripatetik dipahami sebagai intelek, tetapi bagi aliran Israqiyah hal tersebut diidentikkan dengan cahaya (Bagir, 2005: 135). Karena beranggapan bahwa sumber dari segala sesuatu adalah cahaya (nur al-anwar), yang merupakan cahaya absolut dan tidak terbatas oleh semua sinar yang memancar. Nur al-anwar ditempatkan sebagai sumber dari pengetahuan, dan aliran israqiyah telah memberikan tempat untuk pengalaman spiritual yang berupa kilatan tersebut ke dalam dunia ilmiah.

\section{Ilmu dalam Aliran Hikmah Muta'aliyah}

Aliran Hikmah Muta'aliyah atau theosofi transendental dikenal dari pemikiran Mulla Shadra. Mulla Shadra adalah seorang pemikir Islam yang berasal dari Syiraz, di daerah itulah dirinya dilahirkan, sempat menjalani pendidikan di Isfahan selama sepuluh tahun tetapi kemudian kembali ke Syiraz dan di kampung halamannya itu Shadra menghabiskan selama tiga puluh tahun terakhir hidupnya untuk menulis dan mengajar. Mulla Shadra yang bernama lengkap Sadr Al-Din Muhammad Ibn Ibrahim, memiliki pemikiran yang telah sangat berpengaruh dalam dunia pemikiran Islam termasuk di Persia, India, dan juga Irak. Kebesaran pemikirannya tidaklah terlepas dari berbagai pengaruh yang didapatnya dari pemikir-pemikir terdahulunya. Pemikiran Shadra tidak dapat dipungkiri memiliki kedekatan dengan tiap pemikiran pendahulunya seperti halnya aliran Al-Hikmah Masysya'iah dan Al-Hikmah Israqiyah. Petualangan intelektual dan pengalaman ekstaktinya selama bertahun-tahun telah menjadikan dirinya salah satu mistikus dan filsuf besar dalam perkembangan pemikiran Islam. Hal tersebut ditegaskan oleh Fazlur Rahman (dalam Bagir, 2005: 150) bahwa pemikiran Shadra memiliki nilai penting, yang tidak hanya karena dirinya telah mengkaji seluruh warisan pemikiran Islam dan menggabungkan seluruh arus penting dari tiap aliran pemikiran, tetapi terutama karena telah menghasilkan sintesis murni dari semua arus 
tersebut. Shadra, dalam hal ini dapat dikatakan telah menciptakan suatu harmoni baru dari perkawinan pemikiran pendahulunya.

Wujud dalam pemikiran Shadra menjadi term yang teramat sangat penting. Teori Wujudiyah menjadi salah satu poin penting dalam pemahamannya terhadap permasalahan-permasalahan metafisika yaitu tentang yang "ada". Shadra membahasnya secara sangat gamblang dalam karyanya yang berjudul Al-Hikmah Al-Muta'aliyah Fi'al Asfar Al-Aqliyah Al-Arba-ah, karya ini yang dianggap sebagai magnum opus-nya. Menurut Nasr (1996: 81) teori tersebut tidaklah dapat dipahami tanpa memahami lebih dahulu ontologi Avicennan (Ibn Sina) dan kosmologi Suhrawardian, yang bagi Shadra realitas segala sesuatu datang dari wujudnya dan bukan dari kuiditasnya atau mahiyyah (esensinya). Hal tersebut memperlihatkan bagaimana keterkaitan pemikiran Shadra dengan pemikiran paripatetik terutama dari Ibn Sina yang banyak mendapat pengaruh pemikiran Aristoteles dan Plotinos, dan dengan pemikiran illuminasi Suhrawardian. Arah pemikiran Ashalat AlWujud ini cenderung mengarah pada pemahaman aliran eksistensialisme yang memahami bahwa persoalan keberadaan hadir dari struktur eksistensialnya. Shadra mencoba menampilkan suatu pemikiran eksistensialisme ke dalam dunia pemikiran Islam. Dapat dikatakan bahwa dalam pemikirannya ini, Shadra cenderung merunut dari pemikiran paripatetik dengan prinsip-prinsip Aristotelian tentang materi dan bentuk (hylemorphism), yang memahami perubahan tidak hanya terjadi pada kategori aksidental (kuantitas, kualitas, posisi, dan tempat), tetapi juga terjadi pada substansi dari alam semesta (Rahmat, 1993: 79). Dalam hal ini Shadra memahami bahwa terdapat keterkaitan erat antara perubahan dari aksiden dengan substansi, karena aksiden tergantung pada substansi dan perubahan pada aksiden juga mempengaruhi perubahan pada substansinya.

Shadra dalam dunia keilmuan, membagi ilmu menjadi dua macam: ilmu yang diperoleh dari latihan dan belajar (husuli/axquired), dan ilmu yang diperoleh melalui pemberian langsung dari Tuhan (hudhuri/ innate) (Shadra, 1981: 134). Ilmu husuli dalam hal ini adalah ilmu yang keberadaan datanya diperlihatkan dalam gambaran tentang objek pada diri subjek yang terjadi karena interaksi antara subjek dan objek 
yang sama-sama berdiri sendiri. Ilmu hudhuri, di sisi lain adalah ilmu yang sumbernya berasal dari Tuhan secara langsung, yang dalam hal ini objek muncul secara eksistensial dalam diri subjek, keduanya tidak terpisah dan validitasnya tidak terbatas dalam dualisme benar dan salah. Shadra memahami bahwa dalam proses mencapai pengetahuan, dapat dilalui dengan tiga cara, dimulai dari pengalaman rohani kemudian dicari dukungan rasio, lalu diselaraskan dengan syariat; kedua, diawali dari pemikiran rasional kemudian dihayati dengan pengalaman rohani, dan setelah itu dicari dukungan syariat; ketiga, bermula dari ajaran syariat kemudian dirasionalkan, dan seterusnya dipertajam dengan penghayatan rohani (Shadra, 1981: 324). Dapat dipahami bahwa pemikiran Mulla Shadra yang merupakan sintesis dari aliran pemikiran terdahulu menjadikan pengalaman intuitif, proses rasionalisasi, dan syariat Islam sama-sama berperan dalam mencapai kebenaran dalam ilmu. Hal tersebut juga diperjelas oleh paparan Seyyed Hossein Nasr bahwa dalam pemikiran Shadra terdapat tiga jalan menuju kebenaran, yaitu: wahyu (wahy atay syar'), intellection ('aql) dan keterbukaan secara mistik (kasyf), yang semuanya itu dapat dipahami dalam aliran Al-Hikmah Al-Muta'aliyah (Nasr,1996: 79). Sebagai sintesis dari berbagai arus pemikiran, Shadra dalam Al-Hikmah Al-Muta'aliyah menganggap bahwa terdapat pluralitas metode dan sarana mencapai kebenaran pengetahuan. Hal tersebut memperlihatkan bahwa Al-Hikmah Muta'aliyah bukan saja merupakan suatu aliran yang menggabungkan atau merekonsiliasikan tiap-tiap aliran sebelumnya, tetapi juga telah menghasilkan suatu pembaharuan yang memperlihatkannya sebagai suatu aliran yang baru dan menjadi puncak dalam dunia pemikiran Islam.

\section{SIMPULAN}

Hasil penelitian ini menunjukkan bahwa ada karakterisitik yang khas antara keilmuan Barat dan Keilmuan Islam baik dari aspek ontologis, epistemologis dan aksiologisnya. Perbedaan yang paling menyolok adalah beranjak dari pengakuan adanya Tuhan dan tidak. Dari pengakuan eksistensi akan adanya Tuhan ini sangat mempengaruhi konsep ontologi, epistemologi, dan aksiologi ilmu. 
Keilmuan Islam, dalam perkembangannya sebenarnya bermula dari Nabi Muhammad SAW itu sendiri sebagai dasar peletak perkembangan ilmu. Metode keilmuan nabi sebenarnya bersifat langsung (khuduri) dan bersifat iluminatif. Metode ini kemudian diteruskan para sahabat yang sudah menggunakan ijtihad karena semakin berkembangnya persoalan dalam masyarakat sehingga wahyu perlu ditafsirkan, yang selanjutnya mempengaruhi perkembangan pemikiran-pemikiran Islam.

Adapun hakikat ilmu dalam Islam meliputi sarana, proses dan tujuan. Sarana lebih bersifat epistemologis yaitu bahwa Islam menerima rasio dan empiri sekaligus wahyu dan intuisi, sedangkan tujuan ilmu adalah mengungkap kebenaran dalam rangka menuju pada Kebenaran hakiki. Hakikat ilmu kemudian dapat dilihat dari tiga cara pandang ilmu yang bersifat peripatetic, iluminatif dan hikmah al muta'aliyah yang merupakan komninasi dari berbagai tipologi pemikiran.

\section{DAFTAR PUSTAKA}

Abdullah, Amin, 1995, Falsafah Klam di Era Posmodern, Pustaka Pelajar, Yogyakarta.

Ali, Yunasril, 1991, Perkembangan Pemikiran Falsafati dalam Islam, IKAPI, Jakarta.

Anshari, Endang Saifuddin, 1987, Ilmu, Filsafat, dan Agama, Bina Ilmu, Surabaya.

Bagir, Haidar, 2005, Filsafat Islam, Mizan, Jakarta.

Bakker, Anton, 1992, Ontologi atau Metafisika Umum, Kanisius, Yogyakarta.

Black, Antony, 2006, Pemikiran Politik Islam, Serambi Ilmu Semesta, Jakarta.

Durant, Will, 1961, The Story of Philosophy, New York.

Hamdi, Ahmad Zaenul, 2004. Tujuh Filsuf Muslim. Pustaka Pesantren: Yogyakarta.

Hanafi, A, 1976, Pengantar Filsafat Islam, Bulan Bintang, Jakarta.

Huff, Toby E, 2003, The Rise of early Modern Science, Cambridge Univer- 
sity Press, Cambridge.

Hunt, Philip, 2003, Philosphy of Science, The Johns Hopkins University Press

Husaini, Adian, 2013, Filsafat Ilmu, Gema Insani, Depok.

Ibn Sina, 2009, Ahwāl al-Nafs, ter. M.S. Nasrullah, Pustaka Hidayah, Bandung.

Jabiri (al), Muhammad, 1993, Bunyat al-'Aql al-'Arabi, Markaz al Thaqafi, Beirut.

Jalaluddin, 1996, Filsafat Pendidikan Islam, Raja Grafindo Persada, Jakarta.

Kartanegara, Mulyadi, 2002, Panorama Filsafat Islam, Mizan, Bandung.

Kartodirdjo, Sartono, 1990, Ungkapan-Ungkapan Filsafat Sejarah Barat dan Timur, Gramedia, Jakarta.

Labib, Muhsin, 2005, Para Filosof, Al-huda, Jakarta.

Fazlur Rahman, 2000, Filsafat Shadra, ter. Munir A. Pustaka, Bandung.

Melsen, Van Andew, 1961, Science and Technology, The Johns Hopkins University Press

Nasr, Seyyed Hossein, 1996, Intelektual Islam: Teologi, Filsafat, dan Gnosis, Pustaka Pelajar, Yogyakarta.

Nasution, Harun, 1982, Akal dan Wahyu, UI-Press, Depok. 1986, Teologi Islam, UI Press, Jakarta. 1992, Falsafat dan Mistisisme dalam Islam, Bulan Bintang, Jakarta.

Peursen, C. A. Van, 1979, Orientasi Di Alam Filsafat, Gramedia, Jakarta. Rahmat, Jalaluddin, 1993, Hikmah Muta'aliyah: Filsafat Islam Pasca Ibn Rusyd dalam Jurnal Studi-Studi Islam (Juli-September).

Ravertz, Jerome R, 2004, Filsafat ilmu: Sejarah dan Ruang Lingkup Bahasan (Terj. Saut pasaribu). Pustaka Pelajar, Yogyakarta.

Rozak, Abdul, 2012, Ilmu Kalam, Pustaka Setia, Bandung.

Shadra, Mulla, 1981, Al-Hikmah Al-Muta'āliyah fì al-Asfar al-Aqliyyah alArba'ah, Jilid 1. Dar Al-Ihya' Al-Turath al-Arabiyyah, Beirut.

Sofyan, Ayi, 2010, Kapita Selekta Filsafat, Pustaka Setia, Bandung. 
Snijders, Adelbert, 2006, Manusia dan Kebenaran, Pustaka Pelajar, Yogyakarta. 2009, Seluas Segala Kenyataan, Kanisius, Yogyakarta.

Suhartono, Suparlan, 2008, Filsafat Ilmu Pengetahuan, Al-Ruzz, Yogyakarta.

Taftazani, Abul Wafa. 2003. Pengantar Tasawuf Islam, Pustaka, Bandung. Zubaidi, Sujiat, 2013, Kritik Epistemologi dan Model Pembacaan Kontemporer, LESFI, Yogyakarta.

Zubair, Achmad Charris, 2013, Science: As A Humanity Phenomena, UGM Press, Yogyakarta. 